\title{
Executive Compensation and the Cost of Debt
}

\author{
Rezaul Kabir ${ }^{1}$, Hao Li ${ }^{2}$, and Yulia V. Veld-Merkoulova ${ }^{3}$
}

February 2013

\begin{abstract}
This study examines how different components of executive compensation affect the cost of debt. We find that debt-like and equity-like pay components have differing effects: an increase in defined benefit pensions is associated with lower bond yield spread, while higher share holdings lead to higher spreads. In addition, we find that stock options have a mixed impact on the cost of debt whereas cash bonus has no significant impact. Overall, our results indicate that corporate bondholders are fully aware of both risk-taking and risk-avoiding incentives created by various executive pay components.
\end{abstract}

Keywords: Executive compensation, CEO pay, Cost of debt, Yield spread JEL-codes: G31, G34

\footnotetext{
${ }^{1}$ School of Management and Governance, University of Twente, The Netherlands. E-mail: r.kabir@utwente.nl ${ }^{2}$ Chang'An International Trust Co. Ltd, Beijing, China.E-mail: lihao1980@hotmail.com

${ }^{3}$ Adam Smith Business School, University of Glasgow, UK.

E-mail: Yulia.Veld-Merkoulova@glasgow.ac.uk.
}

We thank an anonymous referee as well as Darren Henry, Spencer Martin, Isaac Tabner, Chris Veld, Athena Zhang and seminar participants at the University of Melbourne, University of St Andrews, Finance and Corporate Governance Conference in Melbourne, Scottish BAA in Glasgow, Financial Management Association Conference in New York, British Accounting and Finance Association conference at Brighton, and European Accounting Association Conference in Ljubljana for many helpful comments and suggestions. 


\section{Introduction}

Recent studies demonstrate that a variety of corporate policies and practices affect the cost of debt financing. For example, the corporate governance structure influences the cost of debt, as documented by Anderson et al. (2003), Boubakri and Ghouma (2010), Francis et al. (2010) and Lin et al. (2012). Similarly, the cost of debt impact of corporate practices such as stock repurchases is examined by Maxwell and Stephens (2003), earnings management by Prevost et al. (2008), and beating earnings benchmark by Jiang (2008). Empirical research shows that creditors are concerned with executive pay practices too. In particular, the impact of bonus on the cost of debt is documented by Duru et al. (2005) and that of equity-based compensation by Ertugrul and Hegde (2008) and Devos et al. (2008). Anecdotal evidence reconfirms the concern lenders have regarding executive compensation. ${ }^{4}$

The conventional view in the vast literature of executive compensation has been that pay is structured in such a way that managers receive appropriate incentives to cater the wealth of firm's shareholders. But, the responsibility of corporate managers extends to debtholders as well (this is more evident when a firm shows signs of financial distress) and these investors do take active interest in managerial decisions. In their seminal paper, Jensen and Meckling (1976) argue that if executive compensation only aligns the interests of shareholders and managers (leading to a high pay-performance sensitivity), then there is a strong incentive for managers to undertake

\footnotetext{
${ }^{4}$ Moody's Investors Service (2008) assesses potential implications for creditors of executive compensation plans and practices. In July 2009, Hewitt Associates - a pay consulting firm - discussed changes in executive compensation practices and mentioned "curtailment of accelerated payouts of deferred compensation, eliminating treatment of executives as preferred creditors". The Wall Street Journal recently reported that executive compensation of Hostess Brands Inc. - a renowned private US firm producing breads and snacks - was slashed in 2012 in the aftermath of creditor allegations that the company might have pushed management pay higher in the months leading to its Chapter 11 bankruptcy filing.
} 
more risky investments. They do so because the value of equity-based incentives (i.e. stock options) that managers frequently receive increases with the riskiness of firm's assets. If these risky investments work out favorably, shareholders derive the full amount of value gains. But, this excessive risk-taking comes at the expense of creditors who would suffer when the additional risky investments amplify the default probability of firms. John and John (1993) argue that creditors rationally anticipate the risk-shifting incentive (i.e. increased agency cost of debt) arising from executive compensation, and therefore, require a corresponding increase in risk premium. Hence, firms that use executive compensation to closely align interests of managers and shareholders, are more likely to face a higher borrowing cost. Since the higher cost of borrowing is damaging for firms, especially for those requiring additional debt financing, there is pressure for a reduction in executive compensation. This means executive compensation should be designed to optimize the trade-off between the benefits from risk-shifting and the losses from increased borrowing cost.

In this paper, we investigate how compensations of chief executive officers (CEOs) of firms influence firms' cost of borrowing. The motivation of our study comes from a very limited number of papers that examine executive pay components of US firms and find that bond prices change when capital market receives the news of CEO pay awards. DeFusco et al. (1990) document that bond prices of firms announcing executive stock option plans experience a significant decline. Billet et al. (2010) confirm that bond prices react negatively when CEOs are awarded with equity-based compensation. Recently, Wei and Yermack (2011) observe that the disclosure of defined benefit pensions leads to an increase in bond prices.

Each of these studies document abnormal bond returns by investigating a single pay component at a time. However, if lenders rationally use executive compensation to assess the 
impact on a firm's credit risk, they would not only consider the size of each pay component separately, but also the overall structure of compensation. The relative proportions of various compensation elements convey additional information about the direction and magnitude of managerial risk-taking incentives. This vital gap in the literature leads us to undertake a comprehensive study of executive compensation and assess the direct impact of all major components of executive pay on a firm's cost of debt.

We analyze CEO compensation data of a sample of listed UK firms that had straight bonds outstanding during 2003-2012. Numerous pay components like cash bonus, stock options, shares and pensions are used to estimate CEO compensation. In particular, we employ three different variables to measure pensions: incremental pension (annual change in the value of pensions scaled by total compensation, as used by Sundaram and Yermack, 2007), pension to equity (total value of pension scaled by value of equity holdings, as used by Sundaram and Yermack, 2007), and relative leverage ratio (CEO pension-to-equity ratio divided by firm debtto-equity ratio, as used by Sundaram and Yermack, 2007; Edmans and Liu, 2010; and Anantharaman et al., 2011). We then proceed to examine whether the different executive pay components influence firm's cost of debt financing.

We make two novel contributions in this paper. First, we investigate whether a firm's cost of debt is affected by not only cash-based incentives (bonus) and equity-based incentives (stock and option grants), but also by the debt-like pay (defined benefit pensions). Although the latter form of executive compensation is ubiquitous and has the potential to align the interests of the managers with those of the debtholders, empirical studies barely consider executive pensions, and those that do, often rely on those firms that voluntarily disclose executive pension information. In this paper, we analyze UK companies which have an advantage that the 
regulatory requirement for all listed companies to disclose pensions paid to their directors provides a sample free from self-selection bias. Moreover, we investigate the direct impact of pensions pay on the firm's cost of debt. Prior studies (e.g. Wei and Yermack, 2011) use the event-study approach and document a change in bond prices when pension arrangements are announced.

The second key contribution comes from the fact that although most of the literature treats executive stock options as homogeneous entities, two distinct categories of stock options commonly exist in practice: traditional stock options and performance-vested stock options. The former category has no specific performance target attached, while the latter requires managers to achieve a performance target prior to vesting. In an earlier paper, Johnson and Tian (2000) analytically show that performance-vested stock options provide stronger incentives to increase firm risk compared to traditional stock options. Accordingly, we empirically examine whether bondholders take into account the distinct contractual features of and incentives provided by these two types of executive stock options. In particular, we investigate whether creditors consider the award of traditional stock options (hereafter called TSO) and performance-vested stock options (hereafter called PVSO) compensation differently and charge a differential risk premium. As shown by Gerakos et al. (2005) that the prevalence of performance-vested options is affected by the corporate governance mechanisms, we control for these factors when comparing the two types of options.

In addition to these two major contributions, our study is the first to analyze the link between executive pay and the cost of debt for non-US firms. Because of the scant evidence from the United States, an out-of-sample analysis is important to test whether the current 
knowledge on the reaction by firm's bondholders on executive pay levels also holds for a market with a historically different managerial pay structure.

Our results show that firms awarding their CEOs with higher proportions of defined benefit pensions - a form of compensation that can be viewed as a liability of the firm experience a significant reduction in the cost of debt. The finding is robust to alternative ways of estimating pensions compensation. A $1 \%$ increase in CEO defined benefit pensions leads to a decline in the firm's cost of debt by between 0.7 and 1.6 basis points. Our finding is consistent with that of Wei and Yermack (2011) who document an increase in bond prices associated with the disclosure of pensions and deferred compensation of CEOs. It is also in line with a contemporary paper by Anantharaman et al. (2011) who analyze the cost of debt of private loans and newly issued public bonds. The findings from another recent paper (Wang et al., 2011) that banks charge lower spreads on loans made to firms whose CEOs hold more inside debt support our results too. Defined benefit pensions appear to align the interests of managers and creditors.

Analyzing other types of compensation, we find that, although the annual share grants to CEOs have little impact on the cost of debt, an increase in the total amount of (restricted) stock owned by a CEO leads to significantly higher yield spreads. With regard to stock options, we observe that CEO option grants and holdings are not significantly associated with the firm's cost of debt. We also do not find sufficient evidence that performance-vested stock options outweigh traditional stock options in terms of increasing the firm's cost of debt. Finally, we find that cash bonus payments to CEOs are not related to borrowing costs.

Overall, the results presented in this paper demonstrate that bondholders rationally anticipate risk-taking or risk-avoiding incentives of CEOs by observing different types of compensation awards. A proper adjustment in the structure of executive compensation is 
therefore an effective way to reduce a firm's cost of borrowing, especially when the firm relies heavily on external debt financing.

The remainder of the paper is organized as follows. In Section 2, we briefly review the relevant literature. The hypotheses of the study are developed in Section 3. The methodology and data are described in Sections 4 and 5, respectively. The empirical results are presented in Section 6 . The final section provides a summary and the conclusions of the study.

\section{Literature review}

Executive compensation is primarily investigated in the existing literature from the viewpoint of firm's shareholders. The theoretical framework originates from the agency theory whereby managers are provided incentives to work for the creation of more shareholder wealth. In this regard, risk-averse managers, who are also interested in job security and their own reputation, are reluctant to take on value-increasing but risky investment projects. Equity-based incentives, therefore, motivate managers to undertake risky investments and ultimately create shareholder value.

Several studies provide empirical support for this conjecture. Coles et al. (2006) find that managerial equity-based pay is linked with risk-taking activities such as investments in research and development, higher leverage and less corporate diversification. Sanders and Hambrick (2007) observe that the more option compensation CEOs receive, the more aggressive investments they undertake. $\mathrm{Wu}$ and $\mathrm{Tu}$ (2008) also provide evidence that stock option compensation encourages higher R\&D investments by firms. Chen et al. (2006) analyze optionbased compensation in the banking industry and show that increased use of options induces 
managerial risk-taking. A few studies examine the sensitivity of CEO compensations to stock prices and volatility. Low (2009) and Brockman et al. (2010) show that higher sensitivity of equity-based compensation to stock return volatility (vega) encourages managerial risk-taking behavior.

While the shareholders' interest is served and the agency costs of equity decline because of incentive compensation, John and John (1993) argue that there can be a corresponding increase in the agency costs of debt. The reason is that managers might be inclined to choose risky investments that will be beneficial to shareholders, but detrimental to creditors. This phenomenon is widely known as the shareholder - debtholder conflict. ${ }^{5}$ Obviously, bondholders anticipate this increased risk-taking tendency of managers arising out of incentive pay, and therefore they charge a higher borrowing rate to compensate for any future loss. Bondholders can also impose stricter governance and debt covenants so that managers undertake lower risk investments (King and Wen, 2011).

Although equity-based compensation can hurt bondholders, debt-like compensations can bring bondholders interests in line with those of managers thereby mitigating shareholder bondholder conflict and reducing the agency cost of debt (Jensen and Meckling, 1976). Two common but less investigated forms of such compensation are pensions and deferred compensation (commonly referred to in the literature as inside debt). Bebchuk and Jackson (2005) argue that these are less visible forms of compensation, and their exclusion in the analysis of executive pay not only leads to severe underestimation of the total magnitude of executive pay but also overestimation of the pay - performance relationship. The benefit of debt-like compensation is described by Sundaram and Yermack (2007) as follows: "When top executives

\footnotetext{
${ }^{5} \mathrm{~A}$ growing number of studies provide evidence on the existence of conflicting interests between shareholders and bondholders. See for example, Maxwell and Stephens (2003), Klock et al., (2005), Bryan et al., (2006), Francis et al., (2010) and King and Wen (2011).
} 
receive part of their compensation in debt and part inequity, we would expect them to manage the firm in a way that considers the interests of both debt and equity investors. Classic agency cost of debt problems related to risk-shifting and excessive payouts should diminish in importance when managers hold large pensions or deferred compensation.” Analyzing a sample of large US firms, Sundaram and Yermack document that annual increases in CEO pension entitlements represent about $10 \%$ of total compensation. In another study, Lee and Tang (2011) find that the annual amount of CEO inside debt (the sum of the annual pension incremental value and the annual amount of deferred compensation) of the median US firm represents $42 \%$ of total cash compensation.

While Bebchuk and Jackson (2005) suggest that pensions are used to camouflage paying managers, Edmans and Liu (2011) argue that inside debt component of executive pay can be an efficient way to discourage managerial risk-taking activities. Consistent with this argument, Cassell et al. (2012) find that inside debt holdings are associated with reduced stock return volatility as well as research \& development expenditures. Analyzing CEO pension data of US banks, Tung and Wang (2011) and Kanagaretnam et al. (2012) observe a significant negative relation with bank risk taking during the financial crisis.

To what extent executive compensation influences the cost of debt financing is an interesting area of research. Duru et al. (2005) argue that earnings-based bonus can reduce the cost of debt because it motivates managers to seek stable cash flows to achieve the earnings target and thereby lower the risk of default. Their results show that the level of CEO cash bonus is indeed negatively related with the bond yield spread. Analyzing the sensitivities of CEO wealth to stock prices and volatility, Daniel et al. (2004) observe that credit spreads of corporate bonds increase with both of these sensitivities. On the other hand, Ertugrul and Hegde (2008) 
analyze the effect of options granted to outside directors of US firms and find that an increase in option compensation decreases yield spreads.

A few studies provide indirect evidence. Gerakos (2007) documents a positive relation between bond ratings and CEO pensions pay. Firms with higher quality bond ratings are more likely to compensate their CEOs with pension benefits. Similarly, Sundaram and Yermack (2007) find that an increase in CEO pension values leads to lower probability of default. OrtizMolina (2007) finds that the pay - performance sensitivity, defined as the relation between changes in a CEO's firm-specific wealth and shareholder returns, is lower for firms that issue straight debt whereas it is higher for those issuing convertible debts. The finding indicates that firms adopt incentive compensation in such way that the shareholder - bondholder conflict is mitigated. He also finds that option-based compensation is less attractive for firms suffering from severe shareholder - bondholder conflict (for example, in highly levered firms). Similarly, Bryan et al. (2006) show that firms with higher amount of convertible debt offer more options-based compensation to their CEOs.

If higher incentive compensation aligning shareholder interests with those of managers is detrimental to bondholders, then it should also be reflected in lower bond prices. Therefore, instead of directly examining the effect on the cost of debt, several authors use event study methodology to investigate how bond values are affected by equity-based compensation. Empirical evidence is first provided by DeFusco et al. (1990) who analyze the effect on bond returns when firms announce executive stock option plans. They find that stock returns increase while bond returns decline with these announcements. Billett et al. (2010) document an adverse bond price reaction when CEOs receive new equity-based compensation. Wei and Yermack (2011) study how bondholders (and shareholders) react at the disclosure of CEO's pensions and 
deferred compensation. They find that bond prices rise (and equity prices decline) for firms whose CEOs have relatively high pensions. All these studies analyze US data and show that the announcement or disclosure of equity-based pay and pensions to CEOs is associated with a wealth transfer between shareholders and bondholders.

\section{Hypotheses development}

The literature review in the previous section illustrates that executive compensation can affect the risk-taking behavior of managers, and subsequently, firm's cost of debt financing. Since each compensation component has its own distinctive feature, their effect on the cost of debt capital can be unique too. Therefore, we develop hypotheses on the impact of each incentive pay component separately.

\subsection{Bonus}

Cash bonus is the first compensation element we consider. It is usually related to shortterm performance target like earnings per share. An outcome of such a target is that managers are inclined to decrease certain investments in order to lower short-term expenditures and thereby increase the reported profit. They are also motivated to focus on short-term profitability and generate positive and stable cash flows to be able to meet the performance target. Awarding relatively higher proportion of cash bonus compensation to CEOs would therefore provide more risk-avoiding incentives, which may benefit firm's debtholders (Duru et al., 2005). Accordingly, our first hypothesis is: 
H1: Firms paying higher cash bonus to their CEOs face a lower cost of debt.

\subsection{Pensions}

Pensions are a special form of compensation because it is deferred and can only be accessed upon retirement. There are three basic types of pension arrangements in the UK: the public social security system, occupational pension and private pension plans. The occupational pension category consists of defined benefit (DB) and defined contribution (DC) pension schemes. In the DB pension scheme, the amount of money an employee is expected to receive upon retirement is often "defined" in advance. It is based on the number of years of the employee's service and the final salary when he or she retires. British firms make a minimum pension contribution to an independent trust (in practice, many of the trustees are also insiders, so their independence may be compromised) and the firm's contributions are, with certain limits, tax deductible. These contributions are not taxable to the employees until the funds are withdrawn in retirement.

Defined benefit pension plan for British executives can result in increased managerial risk-avoiding incentives primarily due to two reasons. Firstly, as a consequence of the falling equity prices, lower interest rates and improvements in life expectancy, the DB pension deficit has become increasingly severe among the UK blue chip companies. ${ }^{6}$ This deficit supplemented by pressure from the pension regulator discourages companies from pumping "excess" cash

\footnotetext{
${ }^{6}$ According to the Watson Wyatt pension risk indicators database, the average UK FTSE 350 firm had a DB pension deficit of $£ 254$ million and funding ratio of only $79 \%$ in 2004 (Gupta, 2006). A report written by Pension Capital Strategies in association with JP Morgan mentions that only five of FTSE 100 firms had DB pension surplus during the period of 2007-2009 (The Guardian, 19 May 2010). In May 2012, total pension deficit of 6,432 UK definedbenefit pension schemes stood at $£ 312.1$ billion (The Independent, 13 June 2012).
} 
flows into risky investments. Secondly, executives with a large amount of DB pensions are the potential victims of a bankruptcy - a risk equally faced by other creditors. In the UK, pension liabilities rank equally with other non-preferential unsecured creditors. In terms of recovery rates, Frisby (2007) finds that in about $90 \%$ of the post-Enterprise Act 2002 insolvency cases in the UK, unsecured creditors did not recover any of their claims, and the average recovery rate for unsecured debt was only $2.3 \%$. The pension plan members may be eligible to receive compensation from the Pension Protection Fund (PPF), established by the UK government under the Pension Act of 2004. The PPF is set to pay compensation to the employees if the employer (scheme sponsor) becomes insolvent and the pension trust is unfunded (has a deficit). In this case, $100 \%(90 \%)$ of pension compensation, up to a certain limit, is guaranteed for the member who is above (under) the normal retirement age. However, the guarantee from the Pension Protection Fund is subject to a cap (from April 2012, it is $£ 30,644.85$ per year), which is negligible for the executives. Since the potential loss for executives is huge, they have a strong incentive to avoid company default.

Executives with a defined benefit pension scheme thus effectively become a firm's debtholder. Sundaram and Yermack (2007) argue that defined benefit pensions can be viewed as equivalent to debt, and as such company executives would stand in line with other unsecured creditors in the event of a default. Theoretical argument of using inside debt is put forward by Jensen and Meckling (1976) and Edmans and Liu (2011). Jensen and Meckling (1976) argue that providing compensation by means of inside debt induces CEOs to choose for less risky investments. They are discouraged from taking risky investments which may otherwise increase the probability of default and lower the recovery value. Using the same spirit, Edmans and Liu (2011) argue that inside debt can be a part of an efficient compensation contract as it aligns the 
interests of managers with those of creditors by reducing the risk shifting behavior. Pensions pay thus helps to mitigate the shareholder - debtholder conflict; agency costs of debt reduce. As a result, lenders of firms whose executives have higher amount of inside debt will be satisfied with a lower premium. John and John (1993) also posit that the agency costs of debt can be alleviated through executive compensation. ${ }^{7}$

Empirical support for this argument is provided by Cassell et al. (2012) who document that CEOs with pensions (and deferred compensation) manage their companies conservatively: they adopt less R\&D investments when their inside debt holdings are large. Similar findings are obtained by Tung and Wang (2010) and Kanagaretnam et al. (2012) who investigate a sample of banks during the financial crisis. Empirical research also shows that firms with large CEO pensions have lower default risk. Sundaram and Yermack (2007) analyze pension data of a sample of large US firms and find that CEOs receiving inside debt in the form of pensions manage the firm more conservatively and have lower likelihood of default. In another study, Wei and Yermack (2011) observe that for firms with large inside debt, bond prices rise (and equity prices decline). The finding is evidence that debtholders view inside debt favorably. Examining the cost of borrowing data, Anantharaman et al. (2012) find that a higher CEO inside debt compensation is associated with lower cost of debt. Wang et al. (2011) also observe that in case of firms with larger CEO inside debt holdings, banks demand lower yield spreads and less stringent terms on loans to firms.

The above mentioned theoretical arguments accompanied by empirical findings indicate that by aligning the interests of managers with other debtholders, pensions can be a source of risk

\footnotetext{
${ }^{7}$ Bebchuk and Jackson (2007) question the role of pensions to serve bondholders interests and whether pensions can be a better compensation instrument than that of providing executives with a mixture of equity and debt securities. They claim that pensions are more likely given to camouflage executive pay. While this can be true to some extent, the fact that UK firms have been disclosing pensions pay since 2003 gives insufficient credence to this argument. Gerakos (2007) also finds limited evidence that firms try to camouflage pension benefits.
} 
aversion. As CEOs with large pensions avoid value-creating risky investment projects and/or encourage conservative investment decisions, their incentive for risk-shifting and to expropriate debtholders' wealth reduces. This will subsequently lead creditors to demand a lower yield spread.

Consequently, we formulate the next hypothesis as follows:

H2: Firms whose CEOs receive more defined benefit pensions face a lower cost of debt.

\subsection{Performance-vested versus traditional stock options}

A long established view in the executive compensation literature is that compensation by means of stock options generates strong incentives for risk-increasing investments (Jensen and Meckling, 1976; Guay, 1999). It comes from the fact that options have convex payoff structure: the expected payoff will be zero as long as the share price is below the exercise price, but it can be quite high if the options are in-the-money. Johnson and Tian (2000) point out that two types of executive stock options are frequently awarded to executives: performance-vested stock options (PVSOs) and traditional stock options (TSOs).These options have a distinctive feature: PVSOs have performance targets as a vesting condition, while TSOs have no such targets. This difference provides differential incentives to top managers. First, PVSOs may motivate managers to undertake more risky investments because they cannot exercise these options without achieving the performance benchmarks. Anticipating such risky investment tendency, bondholders will require a higher risk premium. Second, earnings per share which is usually used as the main performance benchmark of PVSOs can motivate managers to engage in opportunistic behavior. Kuang (2008) documents that firms, granting PVSOs to CEOs, exhibit stronger 
incentive for earnings management compared with TSOs. Prevost et al. (2008) link earnings management to the cost of debt and find that earnings management distorts the quality of earnings that is vital for creditors to assess firm's default risk. Therefore, by observing a relatively higher level of PVSO awards to managers, creditors anticipate a stronger incentive for earnings management and charge firms a higher borrowing rate.

These two specific reasons associated with PVSOs lead us to formulate the next hypothesis as follows:

H3: Firms granting their CEOs more PVSOs relative to TSOs face a higher cost of debt.

\subsection{Restricted shares}

The last compensation component we consider is restricted shares. In the UK, most CEOs must meet certain prescribed performance target like total shareholders return before vesting of restricted shares occurs. Hence, CEOs are expected to be motivated to increase stock returns in order to guarantee the vesting of restricted shares. The anticipation of subsequent alignment of the interests of shareholders and CEOs will lead rational debtholders to require a corresponding higher risk premium. Therefore, our hypothesis is:

H4: Firms granting more restricted shares to their CEOs face a higher cost of debt. 


\subsection{Stock options versus restricted stock ownership}

Both restricted shares and stock options are popular vehicles of aligning interests of shareholders and managers. Share ownership directly links CEO's personal wealth to the stock price. Compared to stock options, the relation between CEO's wealth invested in firm's shares is a linear function of stock price rather than a convex one. Hence, the wealth of a CEO with more share ownership might be more sensitive to the decrease of share price compared to the wealth of a CEO with large option holdings. As high risk investments may lead to increased stock return volatility, high level of share ownership may reduce CEO's risk-taking behavior as his or her wealth exposure increases. Analyzing US data, Ortiz-Molina (2006) provides the empirical evidence that the cost of debt soars when ownership increases, while such relation disappears when ownership reaches very high level.

Because of the differences in payoff structures between options and shares, we expect that stock options will create stronger risk-taking incentives compared to share ownership. If rational debtholders perceive this difference, they will require a higher risk premium for firms whose executives hold a relatively large number of stock options than shares. This leads to our final hypothesis:

H5: Stock options held by CEOs increase the cost of debt more than restricted share ownership. 


\section{Methodology}

CEOs receive compensation in a variety of forms, and we therefore analyze each of these pay components. Following the literature, we construct various pay variables as a proportion of total CEO compensation, which is the sum of annual salary, bonus, the estimated values of stock options and restricted shares, and the annual pension increment. As a robustness check, we employ an alternative proxy which is the value of each pay component scaled by total sales of the firm (the results are very similar to those presented in the paper). In order to estimate the impact of pensions in a robust way, three different variables are constructed: incremental pension (annual change in the value of pensions scaled by total compensation), pension to equity (total value of pension scaled by value of equity holdings), and relative leverage ratio (CEO pensionto-equity ratio divided by firm debt-to-equity ratio).

In addition to annual compensation, we analyze the total amount of equity- and debt-like compensation accumulated by a CEO during the service. This accumulated amount has potentially even stronger implications for company policies since CEOs are much more likely to be motivated by the changes in their total wealth rather than by changes in their annual compensation. For stocks and options, we conduct this analysis using the number of equity-based grants because the monetary values can vary based on the valuation assumptions. We define new compensation variables by considering the number of un-exercisable options, and unrestricted and restricted stocks held by the CEO as a proportion of total number of shares outstanding. These new definitions are also useful to check the robustness of our findings.

The yield spread of a corporate bond is used to measure the cost of debt. Following prior literature (e.g. Anderson et al. 2003; Ertugrul and Hegde, 2008; Boubakri and Ghouma, 2010; 
Francis et al. 2010), it is estimated as the difference in yield to maturity between a corporate bond and a government bond with a comparable maturity. The spread is expressed in basis points. ${ }^{8}$ When a firm has multiple bonds outstanding in a year, we use the market value weighted average yield spread. This procedure allows us to use a single representative bond yield per firm.

We perform panel regressions with fixed time effects, using White cross-section robust coefficient covariance estimator and period weights, to measure the effect of executive pay on the cost of debt. The yield spread of corporate bond is used as the dependent variable and the CEO compensation components are used as the explanatory variables. Following prior studies examining yield spread (e.g. Ortiz-Molina, 2006; Ertugrul and Hegde, 2008), the estimated regression model is written as follows:

Spread $_{i, t}=\alpha_{0}+\beta$ Compensation $_{i, t-1}+\sum \lambda$ Bond Characteristics $_{i, t}+$

$\sum \delta$ Firm Characteristics $_{i, t}+\sum \gamma$ Governance Characteristics $_{i, t}+\sum \zeta_{\text {Industry dummies }}{ }_{I}+$ $\sum v$ Year dummies $_{t}+\varepsilon_{i, t}$.

The regression specification considers a lagged relationship because of the fact that bondholders would adjust the bond price once the information on compensation is publicly available. All bond-specific information including credit spread is therefore collected three months after the end of a fiscal year. ${ }^{9}$ The relation between compensation and yield spread is subject to potential endogeneity problem. Our use of a lagged specification can to some extent alleviate this concern.

\footnotetext{
${ }^{8}$ For a few corporate bonds with a maturity longer the longest maturity of government bonds, the yield spread is compared with the longest available maturity of the latter.

${ }^{9}$ Most UK firms publish their annual reports within three months after the end of fiscal year. Therefore, all compensation information is assumed to be publicly available by this date.
} 
Prior literature suggests that several bond and firm characteristics can also influence the cost of debt (see, for example, Ortiz-Molina, 2006; Ertugrul and Hegde, 2008; Boubakri and Ghouma, 2010). These factors are included as control variables in the regression analysis. The bond characteristics we use are bond rating, duration and bond size. For bond rating variable, we convert each rating category into a numerical scale. We assign the lowest rating D a value of 1 and then as the bond rating increases the numerical rating changes by an increment of 1 to the value of 22 for the highest rating Aaa. We use these ratings to create dummy variables for three rating categories: lowest ( $\mathrm{D}$ to $\mathrm{Ba} 3)$, middle ( $\mathrm{Ba} 2$ to $\mathrm{Baa} 2)$ and high (Baa1 and above). The dummy for the middle category is the omitted category in our regressions. ${ }^{10}$ The duration of bond is used to control for differences in bond maturity and the coupon rate. Bond size is used to control the impact of liquidity on yield spread. Large bond size suggests higher liquidity and therefore a lower cost of debt. Following Ortiz-Molina (2007), we use the relative bond size instead of absolute bond size.

The firm characteristics that can affect yield spread include firm size, debt ratio, profitability, market-to-book ratio, firm risk, interest coverage, capital expenditures and R\&D expenses. Many of these firm characteristics are found to be informative in explaining the cost of debt (e.g. Ortiz-Molina; 2007; Ertugrul and Hegde, 2008; Boubakri and Ghouma, 2010). Finally, we use corporate governance characteristics as additional control variables. These include board size, percentage of independent directors on the board and dummy for founder-CEO. The definitions of all these variables are presented in the Appendix. The regressions we perform also incorporate time fixed effects and industry dummies.

\footnotetext{
${ }^{10}$ We also conduct a robustness check by further converting this rating into a rating residual to control for all information other than compensation that can affect bond rating (spread) and that are not captured by other control variables used in the regression. The residual is estimated from the regression where the dependent variable is bond rating and the independent variables are the various compensation components. The results are similar to those reported and are, therefore, not presented.
} 


\section{Sample selection and data description}

The sample consists of all non-financial and non-utility UK firms included in the Financial Times Stock Exchange All Share Index and that had straight bonds in Pound Sterling outstanding during 2003-2012. The sample period of the study starts from 2003 because this is the year when firms were first required to publish detailed information on CEO pensions.

CEO compensation data is mainly collected from BoardEx. This database provides information on the values of most compensation components. Company annual reports are used to collect data on CEO pensions. ${ }^{11}$ Previous empirical studies on executive compensation did not consider pension component of pay because the information was not easily available. However, the disclosure of pension data in the UK is now mandatory thus allowing us to collect the information and to analyze its impact on the cost of debt. We focus on defined benefit pensions because these pension entitlements are a liability of the firm and therefore represent insider debt. We hand collect from company annual reports the actuarial value of the defined benefit pensions. Since the value is often reported as an accumulated figure, we estimate the amount of new pension awarded in a particular year as a year-to-year change in accumulated pension. All firm characteristics data are collected from DataStream.

Since the benchmark for calculating corporate bond yield spread is corresponding UK government bond yield, we exclude bond issues in currencies other than Pound Sterling. The sample firm has on average two bonds outstanding. Information on yield spread and other bond

\footnotetext{
${ }^{11} \mathrm{We}$ are unable to use deferred compensation in our analysis because of very limited disclosure. From the information available, we can only infer that deferred compensation of UK CEOs is not as wide-spread as pensions. Lee and Tang (2011) and Wang et al. (2011) discuss important differences between pensions and deferred compensation. Deferred compensation is also found to be less effective in reducing managerial incentive to engage in excessive risk taking (Wang et al., 2011).
} 
characteristics is collected from DataStream. The total number of firm-year observations in the sample is 287 . Number of firms in each year varies between 29 and 41 . The relatively small sample size is mostly due to the fact that there are few firms with publicly traded bonds. It is consistent with the literature analyzing corporate bonds. For example, Qi et al. (2010) analyze a sample of Eurobond issues from 1980 - 2006 that contain only 180 issues from the UK. ${ }^{12}$ Sample firms are distributed over five different industries as identified by the UK SIC code. Manufacturing sector has the highest number of observations $(39 \%)$. It is followed by the wholesale and retail industry (20\%), and transport, storage and communication industry $(10 \%)$.

Table 1 presents descriptive statistics of major variables used in the empirical analysis. ${ }^{13}$ Panel A provides information on bond characteristics. The average (median) spread over the maturity equivalent government bonds for traded bonds is 188.81 (142.06) basis points with a standard deviation of 137.72 basis points. The average bond in our sample has duration of about 6.15 years. The mean and (median) bond rating is 14.3 (14), which means that about half of bonds in our sample belongs to the investment grade category (Moody's rating Baa2).

(Insert Table 1 here)

Descriptive statistics on annual compensation are provided in Panel B of Table 1. Each compensation component is expressed as a fraction of total CEO compensation and total sales. The mean (median) of total compensation is about $£ 4.45$ million ( $£ 3$ million). The absolute

\footnotetext{
${ }^{12}$ It is possible that analyzing US firms will result in a relatively larger sample, although a recent study by Brockman et al. (2010) also collect bond yield data from DataStream and identify a sample of bond issues for 114 US firms. In addition, the advantage of using a bias-free UK sample (where all firms are required to report pension data) is likely to outweigh the small-sample problem.

${ }^{13}$ To limit the impact of extreme values, the variables are winsorized at the $2.5 \%$ level at each tail. The results without this winsorization are qualitatively similar.
} 
amounts are relatively high because the firms with publicly traded debt are usually the large ones. The CEO of the median firm receives $22.47 \%$ of total compensation as salary and $14.44 \%$ as cash bonus. We observe that performance-vested stock option grants constitute the major portion of option compensation. Share grants also constitute a significant fraction of CEO compensation, which accounts for $38.08 \%$ of annual compensation on average. Finally, an interesting new finding is the amount of defined benefit pension received by the CEO. The annual pension increment is on average $10.43 \%$ of total compensation, which is equal to about $£ 464$ thousands.

Panel $\mathrm{C}$ of Table 1 provides information on $\mathrm{CEO}$ accumulated compensation. On average, CEOs hold un-exercisable traditional stock options, performance-vested stock options and restricted shares for about $0.01 \%, 0.05 \%$ and $0.10 \%$ of total shares outstanding, respectively. Restricted shareholdings dominate the accumulated compensation. The mean ratio of CEO pensions to equity compensation is 0.30 , which is slightly higher than 0.25 reported by Wei and Yermack (2011) for US firms. On average, CEO personal leverage is 1.23 times higher than company leverage. Information on CEO's share ownership is shown in panel D of Table 1 . We find that on average, CEOs in our sample hold about 0.14 percent of firms' total common shares outstanding.

In Panel E of Table 1, we present information on sample firm characteristics. The average (median) firm in the sample has total assets of $£ 15.05$ ( $£ 5.56)$ billion. The long-term debt, on average, amounts to about $30 \%$ of total assets. We find that sample firms have mean (median) profitability of $15 \%(13 \%)$ and market-to-book ratio of 1.34 (1.12). Risk - measured as the standard deviation of profitability over the preceding six years - is quite low ( $2.56 \%$ on average). 
Panel F of Table 1 shows summary statistics of the main corporate governance variables in our sample. The average (median) number of board members is $10.9(10)$, with the average (median) percentage of independent directors of $64.35 \%$ (63.64\%). Fourteen percent of the observations in our sample are firms that are still led by a company founder.

The correlation matrix between key variables is presented in Table 2. We observe that bond spread has significant positive correlation with relative size of the bond issue, CEO ownership, TSO holdings, restricted shareholdings, debt ratio and founding owner. It is negatively related to rating, duration, incremental pension, pension to equity, relative leverage, PVSO and total option grants, firm size, profitability, growth prospects, interest coverage, $R \& D$, and board size, which is largely consistent with our expectations. We also note that relative leverage has a high negative correlation with the debt ratio (by construction). Therefore, to avoid potential multi-collinearity problem, we exclude debt ratio from the regressions where relative leverage is used as one of the explanatory variables. Also, we find expected (partly by construction) high correlations between various components of compensation. Therefore, we estimate series of regressions with these compensation components included both jointly and separately as explanatory variables.

(Insert Table 2 here)

\section{Empirical results}

As discussed in Section 4, panel regressions are used to investigate the impact of CEO compensation on yield spreads of firms. First, we estimate the full regression model with all 
incentive pay components. We also investigate the robustness of our results by estimating a number of regressions dropping out different compensation components, and finally estimating a regression for each individual pay component separately. Results of these regressions, presented in Tables 3, 4 and 5, are discussed in the following paragraphs. ${ }^{14}$ Table 3 shows the results of the impact of annual compensation on the cost of debt while Table 4 reports the impact of accumulated compensation (total holdings of options and shares, as well as all accumulated compensation components together) and Table 5 deals in more detail with pensions. ${ }^{15}$ In each table, the column besides variable names shows the predicted sign for each of the coefficient estimates.

\subsection{The relation between bonus and the cost of debt}

We find that the coefficients of bonus are insignificant in all regressions presented in Table 3 (columns 1 to 4). When we include different pay components in a regression (column 1), we observe that the coefficient for bonus is -1.23 with a $t$-statistic of -1.65 . Sequentially dropping share grants and option grants variables from regressions (columns 2 and 3) does not change this result, with the coefficients of bonus becoming -0.10 and 0.05 , respectively and remaining statistically insignificant. When we test the cash bonus component separately (column 4), the regression coefficient is 0.36 , with the $t$-statistics of 1.18 . These results provide no support to our first hypothesis that more cash bonus lowers the cost of debt. Bonus compensation has no

\footnotetext{
${ }^{14}$ We also check the robustness of regression results presented in Table 3 by employing an alternative measure for all compensation variables (compensation as a percentage of sales). Since these results are qualitative very similar, we do not present these for reasons of brevity.

${ }^{15}$ An alternative way to proxy for CEO incentives derived from equity-based compensation could be to use a CEO's portfolio delta and option vega (Brockman et al., 2010). Data limitations do not allow us to estimate these variables as most companies do not report all the details of CEO option plans.
} 
discernible effect on the cost of debt, after controlling for other firm characteristics, which suggests that accounting-based bonus does not affect the risk-taking incentive for CEOs.

(Insert Table 3 here)

Regarding the control variables, we observe that most of the variables are related to yield spread in the expected direction. The regression coefficients of high (low) rating dummies in all regressions are negative (positive) and statistically significant at the $1 \%$ level, which means that higher-rated bonds are traded at lower credit spreads of about 30 to 37 basis points and lowerrated bonds have spreads higher by about 114 to 133 basis points. Larger firms, companies with lower debt ratio and firms with higher market to book ratios, lower profitability, lower risk and lower R\&D intensity have lower cost of debt. Finally, bond size, duration, interest coverage and capital expenditures have little impact on the credit spread. None of the corporate governance variables (founder CEO, board size and board independence) have any significant economic or statistical impact on the cost of debt.

\subsection{The relation between pensions and the cost of debt}

The results of regressions analyzing the effect of annual increases in pensions on the cost of debt are presented in Table 3 (columns $1-3$ and 5). The coefficients for pensions range from -0.65 (column 3) to -1.56 (column 1), all statistically significant. In column 5 , we examine pensions exclusively, unaffected by other compensation variables, and observe that the coefficient is -0.69 with the statistical significance level of $1 \%$. The finding suggests that an 
increase in CEO pensions by $1 \%$ of annual pay leads to a decrease in the cost of debt by 0.69 basis points. The evidence strongly supports our second hypothesis. It reflects the fact that compensation in the form of company pensions is effective in aligning the interests of CEOs and debtholders. The bond market appears to take into account the debt-like elements of executive pay by requiring a lower risk premium.

The incentive to engage in risk-sifting to expropriate debtholders wealth depends on the accumulated pension benefits and the debt-equity ratio of CEO relative to that of the firm. Therefore, we construct two additional variables to examine the impact of pensions: the pensionto-equity ratio and the relative leverage. These results are presented in Table 4, column 2 (jointly with other accumulated compensation variables), and in Table 5, columns 1 and 2 (as the only compensation variables). We find that both variables have a significant negative effect on yield spread. The more debt-like wealth (pension) a CEO has relative to his equity holding, the more are his interests aligned with those of the debtholders, and the less will be the cost of debt financing.

[Insert Table 4 here]

We continue our investigation of the relation between pensions and the cost of debt by taking into account an important feature: the riskiness of corporate debt. An incentive to reduce the riskiness of the debt is most likely to be effective when this risk is sizable enough. For firms that already have very low credit risk, the additional incentives provided by executive compensation are likely to be less important than for firms that pay a substantial premium to the debtholders to compensate for their credit risk. Therefore, if the negative relation that we observe 
between the amount of debt-like compensation (pensions) and the yield spread is indeed driven by the incentive effects of executive pensions, we should expect that this relation will be stronger for lower-rated corporate bonds.

We test this conjecture in Table 5. In columns 3 to 5 , we focus on the effectiveness of pensions as a risk-avoiding incentive among the lower and higher rated bonds. If pensions provide CEO with risk-avoiding incentives, such incentives will be stronger when the default risk is high (below investment grade bonds). We find that the interaction coefficients of incremental pension and rating below investment grade (column 3), pension-to-equity ratio and rating below investment grade (column 4), and relative leverage and rating below investment grade (column 5) are negative and statistically significant. The finding suggests that the incentive effects of pensions are mostly concentrated among lower-rated, riskier bonds. To examine this relationship further, we conduct an additional analysis on the sub-sample of 145 firm-years with the bond ratings below the investment grade. The results are reported in columns 6 to 8 of Table 5. We find that all pension-related variables (pension increment, pension-to-equity ratio and relative leverage) exhibit a negative relationship with the cost of debt among the lower rated bonds.

(Insert Table 5 here)

Overall, the analysis presented here strongly supports our hypothesis that higher levels of defined benefit pensions lead to a lower cost of debt. This result is likely to be driven by the fact that executive pensions align the interests of outside debtholders (bondholders, for example) and inside debtholders (CEOs). 


\subsection{The relation between stock options and the cost of debt}

We now turn to the examination of the relationship between executive stock options and the cost of debt. We split total option grants into two categories: performance based stock option grants and traditional stock option grants. Hypothesis three postulates that firms granting more PVSOs to their CEOs will experience an increase in the cost of borrowing relative to firms granting TSOs. The regression result presented in Table 3 (column 8) reveals that the coefficients of PVSO and TSO grants are statistically not significant. The Wald test shows that the difference between the two coefficients is statistically insignificant too.

We also analyze the impact of accumulated option holdings, and present the findings in Table 4 (columns 1, 2, 4 and 6). The results initially show that managerial option holdings are not associated with significantly higher cost of debt. But, when we split the total option holdings into PVSO and TSO (column 6), we observe that only the PVSO coefficient is statistically significant and negative, in line with the monitoring hypothesis of Ertugrul and Hegde (2008). However, the Wald test shows that the difference between the two regression coefficients is not statistically significant (p-value of 0.19 ). The result suggests that our hypothesis 3 is rejected as the performance vesting conditions do not significantly affect the relation between managerial option compensation and cost of debt. 


\subsection{The relation between restricted shares and the cost of debt}

The last pay component we analyze is restricted shares. Hypothesis four states that restricted shares may increase a firm's borrowing costs. The regression results are presented in Tables 3 and 4. In Table 3, columns 1 and 7, we use annually awarded share grants as an explanatory variable, while in Table 4, columns 1,2 and 5, we focus on the effects of the accumulated restricted shareholdings of a CEO. In regressions for annual equity compensation, restricted share grants have no statistically significant effect on yield spreads. A possible explanation for this finding is that amount of annually awarded restricted stock changes substantially from year to year. However, the total accumulated restricted share ownership by a CEO (reported in Table 4) significantly increases the cost of debt, showing that the restricted equity compensation is likely to effectively align interests of managers and shareholders by increasing risk-taking by the top managers at the expense of bondholders.

We further examine whether the increase in cost of debt is similar between option holdings and restricted stock ownership. In column 1 (2), the estimated coefficient of option holdings is $-33.63(-59.51)$, both not statistically significant, while those of restricted shareholding are 199.86 (187.04). The Wald test confirms that in both regressions the difference between these coefficients is highly significant (at $0.1 \%$ ). The results suggest that higher managerial restricted shareholdings are seen by the capital market as a much stronger signal that company managers act in the interests of shareholders to the detriment of debtholders. 


\subsection{Robustness checks}

\section{Endogeneity issue}

It is possible that some of our explanatory variables are endogeneously determined. For example, a high correlation between pensions and credit rating could suggest that the CEOs are likely to avoid pension compensation when a firm has low credit rating and high default risk. We start our investigation by analyzing the correlation matrix. We observe no significant correlations between the compensations variables and the firm characteristics that could plausibly cause endogeneity problems. This observation is in line with the results of Ertugrul and Hegde (2008), who found no significant endogeneity in their sample.

In order to formally test the endogeneity issue, we conduct the Hausman test separately for each compensation variable. We use the approach proposed by $\mathrm{Wu}$ (1973) and discussed in detail by Greene (2000). In the first step of the tests, we regress the compensation variables (bonus, pensions, option grants and share grants) on all exogenous variables included in the main regressions (such as bond and firm characteristics and industry and time dummies) and on the set of instrumental variables, which have high correlation with the compensation variables, but not with the credit spreads. The full set of instrumental variables includes log of CEO age, CEO tenure, non-executive directors' tenure, and tangibility of assets. In the second stage of the tests, we re-estimate our main regressions (presented in Table 3) with the cost of debt as dependent variable and with the fitted values from the first stage of the tests added as extra regressors. For all four compensation variables that we consider, the Hausman test does not reject the null hypothesis that OLS estimates are consistent. The values of F statistic for bonus, pensions, option grants and share grants, are respectively $0.75,1.03,0.31$, and 3.73 , all below the $5 \%$ 
critical value of 3.88. Therefore, we conclude that endogeneity does not present a problem in our analysis.

\section{Other control variables and non-linearity effects}

In addition to the control variables that we use in regressions presented in Tables 3 to 5 , it could be argued that other variables might have an impact on the cost of debt and/or the relation between CEO compensation and the cost of debt. Most notably, Sundaram and Yermack (2007) show that CEO age tends to affect the proportion of debt and equity-based incentives in the total CEO compensation package. In addition, the relation between the cost of debt and different components of CEO compensation is not necessarily linear. The marginal effects of various elements of debt and equity-like compensation may be reduced as the levels of such compensation increase.

To test for the robustness of our results to the possible effect of omitted variables and for the non-linearity effects, we estimate additional sets of regressions for each of the Tables 3,4 and 5. We do not present these results in the paper for the sake of brevity. ${ }^{16}$ However, the main results of these tests are as follows. First, CEO age and CEO tenure are not statistically significant in almost any of 22 (in total) regressions that we estimate. The adjusted $\mathrm{R}^{2}$ decreases or remains the same in most cases, and the main results of the study on the relation between the various CEO pay components and the cost of debt are largely unaffected. Second, the results with the non-linear terms are similar. There is no discernible pattern of strong non-linearity effects. For most compensation variables (such as option grants, PVSO grants, option holdings, TSO holdings, PVSO holdings and relative leverage), none of the squared terms are statistically significant across all regressions. For the remaining variables, the significance of non-linear

\footnotetext{
${ }^{16}$ The results are available from the authors on request.
} 
effects varies from regression to regression. For example, squared share grants variable is significant in one regression, but not significant in the other one. Therefore, no consistent results exist for the non-linear effects of compensation variables. For parsimony, we have omitted the squared compensation terms from the final results presented in this paper.

\section{Conclusions}

In this paper we examine whether and how different executive pay components affect firms' cost of debt. We expect to observe a negative relation between pay components which generate risk-avoiding incentives and the cost of debt, and a positive relation between the borrowing cost and pay components which motivate managers to seek risks. We take advantage of the extensive compensation disclosure requirements in the UK and analyze all four major incentive pay components: bonus, pensions, stock options and restricted shares. The findings are mostly consistent with our expectation.

First of all, we document that debt-like compensation (defined benefit pensions) reduces borrowing costs. The provision of defined benefit pensions as a form of compensation makes CEOs the potential debtholders of companies thus aligning their interests with those of other debtholders. Therefore, borrowing costs are lower for firms which provide more defined benefit pensions to CEOs. In addition, we find that most of this effect is concentrated among lower-rated corporate bonds where the default risk is the highest and the risk-reducing incentives are the most valuable.

Secondly, we document that companies with high level of unvested shareholdings are punished by the debt market. Restricted share ownership by a CEO is found to significantly 
increase the cost of debt. The result follows from our argument that the stock holdings motivate managers to take excessive risk, which jeopardizes bondholders' interests.

Finally, we do not find evidence that the cost of debt is positively related to the option grants or options holdings of CEOs. In addition, we investigate whether performance-vested stock options outweigh traditional stock options in increasing the cost of debt. We observe that bondholders react to these two types of stock options slightly differently, but this difference is not statistically significant. The addition of performance-vesting conditions does not increase the impact of option-based compensation on the cost of borrowing. Overall, our study shows that the capital market rationally considers the impact of various executive pay components on managerial risk-taking when pricing publicly traded bonds. Consequently, optimally adjusting executive compensation structure can be a useful tool in reducing the borrowing costs of firms. 


\section{References}

Anantharaman, D., Fang, V., Gong, G., 2011. Inside debt and the design of corporate debt contracts. Unpublished Working Paper. http://ssrn.com/abstract=1743634.

Anderson, R., Mansi, S., Reeb, D., 2003. Founding family ownership and the agency cost of debt. Journal of Financial Economics 68, 263-285.

Bebchuk, L., Jackson, R., 2005. Executive pensions. The Journal of Corporation Law 30, 82355.

Billett, M., Mauer, D., Zhang, Y., 2010. Stockholder and bondholder wealth effects of CEO incentive grants. Financial Management 39, 463-487.

Boubakri, N., Ghouma, H., 2010. Control/ownership structure, creditor rights protection, and the cost of debt financing: international evidence. Journal of Banking \& Finance 34, 2481-2499.

Brockman, P., Martin, X., Unlu, M., 2010. Executive compensation and the maturity structure of corporate debt. Journal of Finance 65, 1123-1161.

Bryan, S., Nash, R., Patel, A., 2006. Can the agency costs of debt and equity explain the changes in executive compensation during the 1990s? Journal of Corporate Finance 12, 516-535.

Cassell, C., Huang, S., Sanchez, J., Stuart, M., 2012. Seeking safety: the relation between CEO inside debt holdings and the riskiness of firm investment and financial policies, Journal of Financial Economics 103, 588-610.

Chen, C., Steiner, T., Whyte, A., 2006. Does stock option-based executive compensation induce risk-taking? An analysis of the banking industry. Journal of Banking and Finance 30, 915-945.

Coles, J., Daniel, N., Naveen, L., 2006. Managerial incentives and risk-taking. Journal of Financial Economics 79, 431-468.

Daniel, N., Martin, S., Naveen, L., 2004. The hidden cost of managerial incentives: evidence from the bond and stock markets. Unpublished Working Paper. http://ssrn.com/abstract=612921.

DeFusco, R., Johnson, R., Zorn, T., 1990. The effect of executive stock options plans on stockholders and bondholders. Journal of Finance 45, 617-627.

Devos, E., Prevost, A., Rao, R., 2008. The structure of executive stock option compensation and the cost of debt. Unpublished Working Paper. Ohio University.

Duru, A., Mansi, S., Reeb, D., 2005. Earnings-based bonus plans and the agency cost of debt. Journal of Accounting and Public Policy 24, 431-447. 
Edmans, A., Liu, Q., 2011. Inside debt. Review of Finance 15, 75-102.

Ertugrul, M., Hegde, S., 2008. Board compensation practices and agency cost of debt. Journal of Corporate Finance 14, 512-531.

Francis, B., Hasan, I., John, K., Waisman, M., 2010. The effect of state antitakeover laws on the firm's bondholders. Journal of Financial Economics 96, 127-154.

Frisby, S., 2007. Interim report on returns to creditors from pre- and post-Enterprise Act procedures insolvency service. Available at:

http://www.insolvency.gov.uk/insolvencyprofessionandlegislation/research/returntocreditors.pdf.

Gerakos, J., 2007. CEO pensions: disclosure, managerial power, and optimal contracting. Unpublished Working Paper. http://ssrn.com/abstract=982180.

Gerakos, J., Goodman, T., Ittner, C., Larcker, D., 2005. The adoption and characteristics of performance stock option grants. Unpublished Working Paper. http://ssrn.com/abstract=701481.

Greene, W., 2000. Econometric Analysis, $4^{\text {th }}$ edition. Prentice-Hall.

Gupta, V., 2006. Pension risk: do employees care. Watson Wyatt Technical Paper.

Guay, W., 1999. The sensitivity of CEO wealth to equity risk: an analysis of the magnitude and determinants. Journal of Financial Economics 53, 43-71.

Jensen, M., Meckling, W., 1976. Theory of the firm: managerial behavior, agency costs, and capital structure. Journal of Financial Economics 3, 305-360.

Jiang, J., 2008. Beating earnings benchmarks and the cost of debt. Accounting Review 83, $377-$ 416.

John, T., John, W., 1993. Top-management compensation and capital structure. Journal of Finance 48, 949-974.

Johnson, S., Tian, Y., 2000. The value and incentive effects of non-traditional executive stock option plans. Journal of Financial Economics 57, 3-34.

Kanagaretnam, K., Lobo, G., Yang, Z., 2012. CEO inside debt, risk taking, earnings management, and financial trouble: pre-crisis and crisis period evidence from the banking industry. Unpublished Working Paper. Presented at the European Accounting Association annual conference.

King, T., Wen, M., 2011. Shareholder governance, bondholder governance, and managerial risktaking. Journal of Banking \& Finance 35, 512-531.

Klock, M., Mansi, S., Maxwell, W., 2005. Does corporate governance matter to bondholders? Journal of Financial and Quantitative Analysis 40, 693-719. 
Kuang, Y., 2008. Performance-vested stock options and earnings management. Journal of Business Finance \& Accounting 35, 1049-1078.

Lee, G., Tang, H., 2011. CEO pension and deferred compensation. Unpublished Working Paper. Seton Hall University.

Lin, C., Ma, Y., Malatesta, P., Xuan, Y., 2012. Ownership structure and the cost of corporate borrowing. Journal of Financial Economics, forthcoming.

Low, A., 2009. Managerial risk-taking behavior and equity-based compensation. Journal of Financial Economics 92, 470-490.

Maxwell, W., Stephens, C., 2003. The wealth effects of repurchases on bondholders. Journal of Finance 58, 895-919.

Ortiz-Molina, H., 2006. Top management incentives and the pricing of corporate public debt. Journal of Financial and Quantitative Analysis 41, 317-340.

Ortiz-Molina, H., 2007. Executive compensation and capital structure: The effects of convertible debt and straight debt on CEO pay. Journal of Accounting and Finance 43, 69-93.

Prevost, A., Skousen, C., Rao, R., 2008. Earnings management and the cost of debt. Unpublished Working Paper. http://ssrn.com/abstract=1083808.

Qi, Y., Roth, L., Wald, J., 2010. Political rights and the cost of debt. Journal of Financial Economics 95, 202-226.

Sanders, G., Hambrick, D., 2007. Swinging for the fences: the effects of CEO stock options on company risk taking and performance. Academy of Management Journal 50, 1055-1078.

Sundaram, R., Yermack, D., 2007. Pay me later: inside debt and its role in managerial compensation. Journal of Finance 52, 1551-1588.

Tung, F., Wang, X., 2011. Bank CEOs, inside debt compensation, and the global financial crisis. Unpublished Working Paper. http://ssrn.com/abstract=1570161.

Wang, C., Xie, F., Xin, X., 2011. Managerial ownership of debt and bank loan contracting. Unpublished Working Paper. http://ssrn.com/abstract=1703473.

Wei, C., Yermack, D., 2011. Investor reactions to CEOs' inside debt incentives. Review of Financial Studies 24, 3813-3840.

Wu, C., 1973. Alternative tests of independence between stochastic regressors and disturbances. Econometrica 41, 733-750.

Wu, J., Tu, R., 2008. CEO stock option pay and R\&D spending: a behavioral agency explanation. Journal of Business Research 60, 482-492. 


\section{Appendix: Variable definitions}

\section{Panel A: Bond characteristics}

Variable Name

Spread

Rating

High Rating

Low Rating

Below

Investment Grade

Bond Size

Duration

\section{Definition}

Bond yield spread expressed in basis points over UK Government securities (DS:SP). For multiple bonds, market value-weighted average is used.

Bond rating of Moody's (DS:MRT) converted to a numerical scale, in which the lowest rating is 1 and the highest (Aaa) is 22 .

Dummy variable equal to one if bond rating is above 14 (Moody's Rating Baa2), the benchmark for investment grade bond, otherwise zero.

Dummy variable equal to one if bond rating is 10 or below (Moody's Rating Ba3), otherwise zero.

Dummy variable equals one if rating is no more than 14 (Moody's Rating Baa2), the benchmark for investment grade bond, otherwise zero.

Relative size of bonds calculated as the market value of bonds (DS:MV) scaled by book value of total assets (WC 02999).

Duration of bonds (DS:DM). For multiple bonds, market value-weighted average is used.

\section{Panel B: Firm characteristics}

Variable Name

Firm Size

Debt Ratio

Profitability

Market-to-Book ratio

Risk

Interest Coverage

Capital Expenditure
Definition

The natural logarithm of book value of total assets (WC 02999).

Book value of long-term debt (WC 03251) scaled by book value of total assets (WC 02999).

Operating income (WC 01250) before depreciation (WC 01151) scaled by book value of total assets (WC 02999).

Book value of total debt (WC 03255) plus the market value of equity(DS:MV) scaled by book value of total assets (WC 02999).

Standard deviation of Profitability calculated using data of years t-6 to t-1.

Ratio of operating income before depreciation to interest expense (WC 01251).

Annual capital expenditure (WC 04601) scaled by total sales (WC 01001). 
Research and

Annual R\&D spending (WC 01201) scaled by total sales (WC 01001).

Development

\section{Panel C: CEO compensation}

Variable Name

Total Compensation

Salary

Bonus

Incremental Pension

Pension to Equity

Relative Leverage

TSO Grants

PVSO Grants

Option Grants

Share Grants

TSO Holding

PVSO Holding

Option Holding

Restricted

Shareholding

Ownership
Definition

Sum of salary, bonus, the estimated values of stock options and restricted shares grants, and the pension increment in a particular year

Salary scaled by total compensation

Cash bonus scaled by total compensation.

Year-to-year change in the actuarial value of defined benefit pension scaled by total compensation.

The total transfer value of defined benefit pension scaled by the estimated value of equity holdings (including ownership, restricted shares and options).

CEO pension-to-equity ratio divided by the firm's debt-to-equity ratio.

Estimated value of traditional stock option grants scaled by total compensation.

Estimated value of performance-vested stock option grants scaled by total compensation.

The sum of TSO grants and PVSO grants.

Estimated value for restricted share grants scaled by total compensation.

Number of un-exercisable traditional stock options scaled by total number of shares outstanding (DS:NOSH).

Number of un-exercisable performance-vested stock options scaled by total number of shares outstanding (DS:NOSH).

The sum of TSO holding and PVSO holding

Number of restricted shares held by the CEO scaled by total number of shares outstanding (DS:NOSH)

Number of unrestricted shares held by the CEO scaled by total number of shares outstanding (DS:NOSH) 


\section{Panel D: Corporate governance characteristics}

\begin{tabular}{ll}
$\begin{array}{l}\text { Variable Name } \\
\text { Founder }\end{array}$ & \multicolumn{1}{c}{ Definition } \\
Board Size & The natural logarithm of the total number of directors. \\
Board & The percentage of non-executive directors in the Board. \\
Independence &
\end{tabular}


Table 1. Descriptive statistics

The sample consists of straight bond issues in Pound Sterling during 2003-2012 by non-financial and non-utility UK firms. All variables are defined in the Appendix.

\section{Variables \\ Panel A. Bond characteristics}

Spread (Basis Points)

Rating

Low Rating

Bond Size (\%)

Duration (Years)

Panel B. Annual compensation

Salary (\%)

Bonus (\%)

TSO Grants (\%)

PVSO Grants (\%)

Option Grants (\%)

Share Grants (\%)

Incremental Pension (\%)

Total Compensation ( $\mathrm{fm}$ )

Panel C. Accumulated compensation

TSO Holding (\%)

PVSO Holding (\%)

Option Holding (\%)

Restricted Shareholding (\%)

Pension to Equity

Relative Leverage

Panel D. Other equity incentives

Ownership (\%)

Panel E. Firm characteristics

Firm Size ( $£ b n$ )

Debt Ratio (\%)

Profitability (\%)

Market-to-Book Ratio

Risk (\%)

Interest Coverage

Capital Expenditures

Research and Development

Panel F. Governance characteristics

Founder

Board Size (number of directors)

Board Independence (\%)
Mean

188.81

14.30

0.51

1.38

6.15

24.95

15.62

0.90

8.42

9.89

38.08

10.43

4.45

0.01

0.05

0.06

0.10

0.30

1.23

0.14

15.05

29.93

15.11

1.34

2.56

10.16

7.09

0.79

0.14

10.94

64.35
Median

$$
142.06
$$

14.00

1.00

0.87

5.91

22.47

14.44

0.00

0.00

0.07

41.15

0.00

3.00

0.00

0.02

0.03

0.05

0.00

0.01

0.03

5.56

25.40

13.04

1.12

1.66

7.51

5.32

0.00

0.00

10.00

63.64

40
St. Dev.

Quartile 1

Quartile 3

137.72

101.06

227.87

2.12

13.00

15.62

0.50

0.00

1.00

1.55

0.51

1.81

2.64

4.25

7.72

32.20

21.45

0.00

13.50

14.14

15.55

16.40

23.98

56.26

15.42

18.11

3.96

5.79

1.68

0.04

0.00

0.00

0.06

0.08

0.09

0.10

0.12

0.12

0.48

0.43

2.37

1.14

0.00

0.26

0.01

0.11

$$
2.77
$$

2.39

11.34

17.73

16.09

41.26

7.54

9.38

17.75

0.71

0.84

1.62

2.56

0.98

3.00

8.16

4.92

12.43

5.12

9.24

2.42

3.36

0.23

0.00

0.00

0.35

0.00

13.00

2.52

9.00

75.00 


\section{Table 2. Correlation matrix}

This table reports correlations between main variables. All variables are defined in the Appendix. The correlations, which are significant at $10 \%$ level, are in bold.

\begin{tabular}{|c|c|c|c|c|c|c|c|c|c|c|c|c|c|c|c|c|c|c|c|c|c|c|c|c|c|c|c|}
\hline 1) Spread & 1.00 & & & & & & & & & & & & & & & & & & & & & & & & & & \\
\hline 2) Rating & -0.39 & 1.00 & & & & & & & & & & & & & & & & & & & & & & & & & \\
\hline 3) Bond Size & 0.11 & -0.09 & 1.00 & & & & & & & & & & & & & & & & & & & & & & & & \\
\hline 4) Duration & -0.15 & 0.27 & 0.23 & 1.00 & & & & & & & & & & & & & & & & & & & & & & & \\
\hline 5) Bonus & 0.03 & 0.02 & 0.12 & 0.02 & 1.00 & & & & & & & & & & & & & & & & & & & & & & \\
\hline $\begin{array}{l}\text { f) Incremental } \\
\text { ension }\end{array}$ & -0.16 & 0.02 & -0.13 & 0.17 & -0.30 & 1.00 & & & & & & & & & & & & & & & & & & & & & \\
\hline $\begin{array}{l}\text { 7) Pension to } \\
\text { quity }\end{array}$ & -0.14 & -0.02 & -0.09 & 0.16 & -0.25 & 0.73 & 1.00 & & & & & & & & & & & & & & & & & & & & \\
\hline $\begin{array}{l}\text { Relative } \\
\text { everage }\end{array}$ & -0.19 & 0.05 & -0.21 & 0.03 & -0.20 & 0.57 & 0.80 & 1.00 & & & & & & & & & & & & & & & & & & & \\
\hline ) TSO Grants & -0.05 & 0.00 & -0.09 & -0.03 & -0.16 & -0.03 & -0.02 & -0.03 & 1.00 & & & & & & & & & & & & & & & & & & \\
\hline 0) PVSO Grants & -0.14 & -0.08 & -0.03 & 0.00 & -0.19 & -0.02 & 0.00 & -0.03 & -0.06 & 1.00 & & & & & & & & & & & & & & & & & \\
\hline $\begin{array}{l}\text { 11) Option } \\
\text { irants }\end{array}$ & -0.17 & -0.06 & -0.08 & 0.01 & -0.25 & -0.04 & -0.01 & -0.03 & 0.40 & 0.88 & 1.00 & & & & & & & & & & & & & & & & \\
\hline 2) Share Grants & 0.04 & 0.15 & -0.06 & -0.19 & -0.22 & -0.38 & -0.33 & -0.21 & -0.08 & -0.46 & -0.46 & 1.00 & & & & & & & & & & & & & & & \\
\hline 3) Ownership & 0.13 & -0.15 & 0.33 & 0.16 & -0.04 & 0.07 & -0.01 & -0.04 & -0.09 & -0.08 & -0.12 & -0.06 & 1.00 & & & & & & & & & & & & & & \\
\hline 14) TSO Holding & 0.10 & 0.12 & 0.13 & 0.04 & -0.10 & -0.13 & -0.12 & -0.10 & 0.15 & 0.07 & 0.12 & 0.02 & -0.04 & 1.00 & & & & & & & & & & & & & \\
\hline $\begin{array}{l}\text { 15) PVSO } \\
\text { Holding }\end{array}$ & 0.02 & -0.25 & 0.02 & 0.01 & -0.04 & 0.14 & 0.14 & 0.06 & -0.07 & 0.51 & 0.43 & -0.38 & -0.11 & 0.07 & 1.00 & & & & & & & & & & & & \\
\hline $\begin{array}{l}\text { 16) Option } \\
\text { Iolding }\end{array}$ & 0.08 & -0.11 & 0.09 & 0.04 & -0.08 & 0.01 & 0.03 & -0.03 & 0.01 & 0.44 & 0.40 & -0.28 & -0.11 & 0.60 & 0.80 & 1.00 & & & & & & & & & & & \\
\hline $\begin{array}{l}\text { 17) Restricted } \\
\text { Shareholding }\end{array}$ & 0.39 & -0.24 & 0.33 & -0.07 & 0.03 & -0.22 & -0.18 & -0.17 & -0.09 & -0.28 & -0.30 & 0.34 & 0.31 & 0.17 & -0.17 & -0.06 & 1.00 & & & & & & & & & & \\
\hline 8) Firm Size & -0.13 & 0.34 & -0.55 & -0.17 & -0.23 & -0.03 & -0.14 & -0.03 & 0.24 & 0.04 & 0.17 & 0.28 & -0.40 & -0.02 & -0.16 & -0.12 & -0.33 & 1.00 & & & & & & & & & \\
\hline 19) Debt Ratio & 0.31 & -0.12 & 0.60 & 0.28 & 0.13 & -0.16 & -0.16 & -0.38 & -0.10 & -0.07 & -0.12 & -0.02 & 0.11 & 0.16 & 0.02 & 0.14 & 0.31 & -0.41 & 1.00 & & & & & & & & \\
\hline 2) Profitability & -0.11 & 0.06 & 0.15 & -0.11 & 0.16 & 0.00 & -0.12 & -0.10 & -0.07 & 0.00 & -0.05 & 0.06 & 0.14 & -0.11 & -0.13 & -0.17 & -0.04 & -0.18 & 0.12 & 1.00 & & & & & & & \\
\hline 1) MB Ratio & -0.24 & 0.16 & 0.20 & 0.03 & 0.24 & -0.06 & -0.15 & -0.19 & -0.09 & -0.01 & -0.06 & 0.09 & 0.04 & -0.13 & -0.19 & -0.22 & -0.10 & -0.13 & 0.23 & 0.84 & 1.00 & & & & & & \\
\hline 22) Risk & 0.05 & -0.07 & -0.03 & -0.26 & 0.05 & -0.09 & -0.14 & -0.06 & 0.13 & -0.02 & 0.04 & 0.06 & -0.10 & -0.09 & -0.05 & -0.09 & -0.05 & -0.05 & 0.06 & 0.48 & 0.42 & 1.00 & & & & & \\
\hline $\begin{array}{l}\text { 23) Interest } \\
\text { Coverage }\end{array}$ & -0.28 & 0.32 & -0.29 & -0.20 & -0.08 & 0.11 & 0.01 & 0.25 & 0.01 & 0.03 & 0.04 & 0.12 & 0.04 & -0.09 & -0.17 & -0.20 & -0.23 & 0.32 & -0.56 & 0.42 & 0.23 & 0.13 & 1.00 & & & & \\
\hline $\begin{array}{l}\text { 24) Capital } \\
\text { xpenditures }\end{array}$ & -0.02 & 0.23 & -0.02 & 0.17 & -0.19 & 0.05 & 0.01 & 0.12 & 0.14 & -0.04 & 0.04 & 0.06 & -0.03 & 0.12 & -0.08 & 0.01 & -0.06 & 0.10 & 0.05 & -0.06 & -0.13 & 0.12 & 0.12 & 1.00 & & & \\
\hline $\begin{array}{l}\text { 25) Research and } \\
\text { evelopment }\end{array}$ & -0.16 & 0.30 & -0.10 & 0.31 & 0.02 & 0.05 & 0.00 & -0.01 & 0.02 & 0.19 & 0.18 & -0.03 & -0.15 & 0.00 & 0.01 & -0.01 & -0.15 & 0.20 & -0.10 & 0.28 & 0.32 & 0.08 & 0.18 & -0.14 & 1.00 & & \\
\hline ) Founder & 0.13 & -0.20 & 0.01 & 0.21 & 0.04 & 0.05 & 0.00 & 0.03 & -0.08 & -0.15 & -0.17 & -0.09 & 0.63 & -0.08 & -0.17 & -0.18 & 0.19 & -0.26 & 0.03 & 0.08 & 0.04 & -0.03 & 0.02 & 0.01 & -0.13 & 1.00 & \\
\hline $\begin{array}{l}\text { Board } \\
\text { lependence }\end{array}$ & 0.05 & 0.07 & -0.26 & -0.31 & 0.04 & -0.13 & -0.17 & -0.13 & 0.05 & -0.09 & -0.05 & 0.32 & -0.26 & 0.04 & -0.20 & -0.13 & 0.06 & 0.41 & -0.06 & 0.20 & 0.23 & 0.20 & 0.15 & 0.00 & 0.19 & -0.15 & 1.00 \\
\hline Board Size & -0.22 & 0.30 & -0.32 & -0.03 & -0.11 & 0.11 & 0.03 & 0.04 & 0.20 & 0.02 & 0.12 & 0.12 & -0.28 & -0.06 & -0.05 & -0.08 & -0.26 & 0.59 & -0.27 & 0.03 & 0.12 & 0.15 & 0.14 & 0.06 & 0.19 & -0.11 & 0.25 \\
\hline
\end{tabular}


Table 3. Annual compensation and the cost of debt

The table presents results of the regressions of the bond yield spread on annual CEO compensation components. All variables are defined in the Appendix. Fixed time and industry effects are included. All regressions include 287 observations. The White heteroscedasticity-corrected $t$-statistics are reported in parentheses. The asterisks $*, * *, * *$ denote statistical significance at $10 \%, 5 \%$, and $1 \%$ level, respectively.

\begin{tabular}{|c|c|c|c|c|c|c|c|c|c|}
\hline Variables & Exp. Sign & (1) & (2) & (3) & (4) & $(5)$ & (6) & (7) & (8) \\
\hline Intercept & & $\begin{array}{l}359.07 * * * \\
(5.89)\end{array}$ & $\begin{array}{l}322.03 * * * \\
(7.06)\end{array}$ & $\begin{array}{l}320.75 * * * \\
(7.18)\end{array}$ & $\begin{array}{l}265.69 * * * \\
(14.62)\end{array}$ & $\begin{array}{l}285.51 * * * \\
(19.10)\end{array}$ & $\begin{array}{l}271.63 * * * \\
(20.50)\end{array}$ & $\begin{array}{l}277.54 * * * \\
(16.07)\end{array}$ & $\begin{array}{l}264.96 * * * \\
(21.36)\end{array}$ \\
\hline Bonus & $(-)$ & $\begin{array}{l}-1.23 \\
(-1.65)\end{array}$ & $\begin{array}{l}-0.10 \\
(-0.22)\end{array}$ & $\begin{array}{l}0.05 \\
(0.10)\end{array}$ & $\begin{array}{l}0.36 \\
(1.18)\end{array}$ & & & & \\
\hline Incremental Pension & $(-)$ & $\begin{array}{l}-1.56^{* * * *} \\
(-3.16)\end{array}$ & $\begin{array}{l}-0.74 * * \\
(-2.11)\end{array}$ & $\begin{array}{l}-0.65^{*} \\
(-1.80)\end{array}$ & & $\begin{array}{l}-0.69 * * * \\
(-2.63)\end{array}$ & & & \\
\hline Option Grants & $(+)$ & $\begin{array}{l}-1.35^{* *} \\
(-1.98)\end{array}$ & $\begin{array}{l}-0.38^{*} \\
(-1.95)\end{array}$ & & & & $\begin{array}{l}-0.23 \\
(-1.34)\end{array}$ & & \\
\hline Share Grants & $(+)$ & $\begin{array}{l}-0.98 \\
(-1.59)\end{array}$ & & & & & & $\begin{array}{l}-0.01 \\
(-0.03)\end{array}$ & \\
\hline TSO Grants & $(+)$ & & & & & & & & $\begin{array}{l}-2.09 \\
(-1.54)\end{array}$ \\
\hline PVSO Grants & $(+)$ & & & & & & & & $\begin{array}{l}-0.01 \\
(-0.06)\end{array}$ \\
\hline High Rating & $(-)$ & $\begin{array}{l}-30.00 * * * \\
(-3.70)\end{array}$ & $\begin{array}{l}-33.03 * * * \\
(-3.96)\end{array}$ & $\begin{array}{l}-32.59 * * * \\
(-3.87)\end{array}$ & $\begin{array}{l}-36.25 * * * \\
(-3.87)\end{array}$ & $\begin{array}{l}-36.87 * * * \\
(-3.93)\end{array}$ & $\begin{array}{l}-35.07 * * * \\
(-3.81)\end{array}$ & $\begin{array}{l}-35.36 * * * \\
(-3.82)\end{array}$ & $\begin{array}{l}-31.21 * * * \\
(-2.83)\end{array}$ \\
\hline Low Rating & $(+)$ & $\begin{array}{l}133.23^{* * *} \\
(6.13)\end{array}$ & $\begin{array}{l}127.38^{* * *} \\
(5.82)\end{array}$ & $\begin{array}{l}124.88^{* * *} \\
(5.60)\end{array}$ & $\begin{array}{l}112.56^{* * *} \\
(4.91)\end{array}$ & $\begin{array}{l}123.39 * * * \\
(5.12)\end{array}$ & $\begin{array}{l}115.08^{* * * *} \\
(5.14)\end{array}$ & $\begin{array}{l}114.02 * * * \\
(4.92)\end{array}$ & $\begin{array}{l}113.63^{* * * *} \\
(5.11)\end{array}$ \\
\hline Bond Size & $(-)$ & $\begin{array}{l}-1.79 \\
(-0.56)\end{array}$ & $\begin{array}{l}-1.85 \\
(-0.61)\end{array}$ & $\begin{array}{l}-1.96 \\
(-0.64)\end{array}$ & & & & & \\
\hline Duration & $(-)$ & $\begin{array}{l}-2.12 \\
(-0.71)\end{array}$ & $\begin{array}{l}-1.93 \\
(-0.52)\end{array}$ & $\begin{array}{l}-1.92 \\
(-0.64)\end{array}$ & & & & & \\
\hline Firm Size & $(-)$ & $\begin{array}{l}-2.39 \\
(-0.33)\end{array}$ & $\begin{array}{l}-5.16 \\
(-0.69)\end{array}$ & $\begin{array}{l}-6.19 \\
(-0.83)\end{array}$ & $\begin{array}{l}-6.88 * * * \\
(-4.17)\end{array}$ & $\begin{array}{l}-8.49 * * * \\
(-5.63)\end{array}$ & $\begin{array}{l}-6.84 * * * \\
(-4.02)\end{array}$ & $\begin{array}{l}-7.55^{* * *} \\
(-4.21)\end{array}$ & $\begin{array}{l}-5.87 * * * \\
(-2.93)\end{array}$ \\
\hline Debt Ratio & $(+)$ & $\begin{array}{l}1.13 * * \\
(2.26)\end{array}$ & $\begin{array}{l}1.21 * * \\
(2.10)\end{array}$ & $\begin{array}{l}1.21 * * \\
(2.05)\end{array}$ & $\begin{array}{l}1.42 * * * \\
(3.37)\end{array}$ & $\begin{array}{l}1.33 * * * \\
(3.23)\end{array}$ & $\begin{array}{l}1.43 * * * \\
(3.63)\end{array}$ & $\begin{array}{l}1.43 * * * \\
(3.54)\end{array}$ & $\begin{array}{l}1.34 * * * \\
(2.97)\end{array}$ \\
\hline Profitability & $(-)$ & $\begin{array}{l}2.89^{*} \\
(1.95)\end{array}$ & $\begin{array}{l}3.08^{* *} \\
(2.16)\end{array}$ & $\begin{array}{l}2.91 * * \\
(1.99)\end{array}$ & $\begin{array}{l}1.73^{* *} \\
(1.98)\end{array}$ & $\begin{array}{l}1.86^{* *} \\
(2.14)\end{array}$ & $\begin{array}{l}1.83^{* *} \\
(2.00)\end{array}$ & $\begin{array}{l}1.67^{*} \\
(1.66)\end{array}$ & $\begin{array}{l}1.82 * * \\
(1.99)\end{array}$ \\
\hline Market-to-Book Ratio & $(-)$ & $\begin{array}{l}-54.05^{* * *} \\
(-4.10)\end{array}$ & $\begin{array}{l}-59.39 * * * \\
(-5.03)\end{array}$ & $\begin{array}{l}-58.46^{* * *} \\
(-4.85)\end{array}$ & $\begin{array}{l}-57.22 * * * \\
(-5.54)\end{array}$ & $\begin{array}{l}-54.53 * * * \\
(-5.65)\end{array}$ & $\begin{array}{l}-57.02 * * * \\
(-5.95)\end{array}$ & $\begin{array}{l}-55.60 * * * \\
(-5.50)\end{array}$ & $\begin{array}{l}-57.12 * * * \\
(-5.83)\end{array}$ \\
\hline Risk & $(+)$ & $\begin{array}{l}2.81 \\
(1.33)\end{array}$ & $\begin{array}{l}2.93 \\
(1.36)\end{array}$ & $\begin{array}{l}2.85 \\
(1.31)\end{array}$ & $\begin{array}{l}4.47 * * * \\
(2.71)\end{array}$ & $\begin{array}{l}3.84 * * \\
(2.21)\end{array}$ & $\begin{array}{l}4.50 * * * \\
(2.74)\end{array}$ & $\begin{array}{l}4.49 * * * \\
(2.75)\end{array}$ & $\begin{array}{l}4.87 * * * \\
(3.06)\end{array}$ \\
\hline Founder & $(+)$ & $\begin{array}{l}12.90 \\
(1.33)\end{array}$ & $\begin{array}{l}14.63 \\
(1.03)\end{array}$ & $\begin{array}{l}16.28 \\
(1.15)\end{array}$ & & & & & \\
\hline Board Size & $(+)$ & $\begin{array}{l}-5.19 \\
(-0.19)\end{array}$ & $\begin{array}{l}-4.40 \\
(-0.13)\end{array}$ & $\begin{array}{l}-2.57 \\
(-0.08)\end{array}$ & & & & & \\
\hline Board Independence & $(-)$ & $\begin{array}{l}-0.24 \\
(-0.49)\end{array}$ & $\begin{array}{l}-0.49 \\
(-1.04)\end{array}$ & $\begin{array}{l}-0.47 \\
(-1.02)\end{array}$ & & & & & \\
\hline Interest Coverage & $(-)$ & $\begin{array}{l}-1.34 \\
(-1.19)\end{array}$ & $\begin{array}{l}-1.35 \\
(-1.09)\end{array}$ & $\begin{array}{l}-1.35 \\
(-1.10)\end{array}$ & & & & & \\
\hline
\end{tabular}


Capital Expenditure

Research and

Development

No. of Obs.

Adjusted $\mathrm{R}^{2}$

Wald Test: Chi Square ( $p$-value), $\mathrm{H}_{0}: \beta_{\text {TSO Grants }}=\beta_{\text {PVSO Grants }}$

$\begin{array}{lllllllll}(+) & -2.19 & -2.29 & -2.30 & -2.64 * & -2.61 * & -2.68^{*} & -2.72 * & -2.23 \\ & (-1.45) & (-1.50) & (-1.53) & (-1.90) & (-1.85) & (-1.84) & (-1.96) & (-1.40) \\ (+) & 4.66^{* * *} & 4.68 * * * & 4.49 * * * & 3.61^{* * *} & 3.42^{* * *} & 3.76^{* * *} & 3.65^{* * *} & 3.48^{* * *} \\ & (3.58) & (3.50) & (3.14) & (4.18) & (3.32) & (4.47) & (4.07) & (4.09) \\ & 287 & 287 & 287 & 287 & 287 & 287 & 287 & 287 \\ & 0.54 & 0.53 & 0.53 & 0.52 & 0.53 & 0.52 & 0.52 & 0.52\end{array}$

$2.13(0.14)$ 


\section{Table 4. Accumulated incentives and the cost of debt}

This table presents results of regressing bond yield spread on accumulated ownership of restricted shares, unrestricted shares and option holdings and on the relative leverage of CEOs. All variables are defined in the Appendix. Fixed time and industry effects are included. All regressions include 287 observations. The White heteroscedasticity-corrected $t$-statistics are reported in parentheses. The asterisks *,**,*** denote statistical significance at $10 \%, 5 \%$, and $1 \%$ level, respectively.

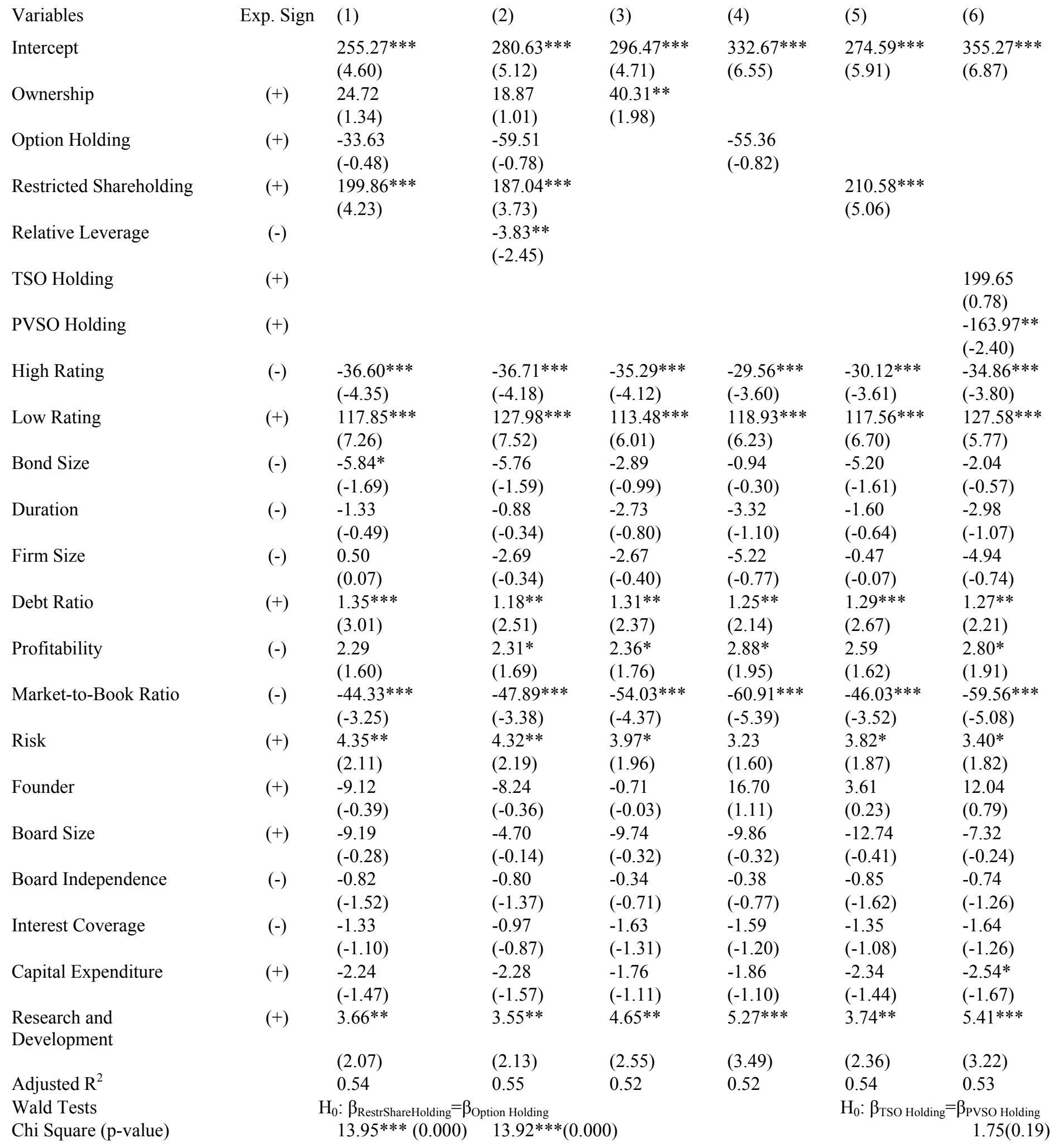


Table 5. Pensions, credit quality and the cost of debt

This table presents results of regressing bond yield spread on pension-related annual and accumulated CEO compensation components. All variables are defined in the Appendix. The last three columns are estimated only for observations with low bond ratings. Fixed time and industry effects are included. The White heteroscedasticity-corrected $t$-statistics are reported in parentheses. The asterisks $* * *, * * *$ denote statistical significance at $10 \%, 5 \%$, and $1 \%$ level, respectively.

\begin{tabular}{|c|c|c|c|c|c|c|c|c|c|}
\hline Variables & Exp. Sign & (1) & (2) & (3) & (4) & (5) & (6) & (7) & (8) \\
\hline Intercept & & $\begin{array}{l}336.24 * * * \\
(7.12)\end{array}$ & $\begin{array}{l}377.00 * * * \\
(7.76)\end{array}$ & $\begin{array}{l}353.09 * * * \\
(7.34)\end{array}$ & $\begin{array}{l}344.00 * * * \\
(6.91)\end{array}$ & $\begin{array}{l}401.05 * * * \\
(7.56)\end{array}$ & $\begin{array}{l}15.97 \\
(0.09)\end{array}$ & $\begin{array}{l}13.25 \\
(0.07)\end{array}$ & $\begin{array}{l}68.44 \\
(0.36)\end{array}$ \\
\hline $\begin{array}{l}\text { Incremental } \\
\text { Pension }\end{array}$ & $(-)$ & & & 0.45 & & & $-1.14 * * *$ & & \\
\hline $\begin{array}{l}\text { Pension } \\
\text { Pension to } \\
\text { Equity }\end{array}$ & $(-)$ & $\begin{array}{l}-18.29 * * \\
(-1.97)\end{array}$ & & $(1.11)$ & $\begin{array}{l}1.06 \\
(0.08)\end{array}$ & & $(-2.95)$ & $\begin{array}{l}-23.52 \\
(-1.47)\end{array}$ & \\
\hline $\begin{array}{l}\text { Relative } \\
\text { Leverage }\end{array}$ & $(-)$ & & $\begin{array}{l}-5.36^{* * * *} \\
(-4.24)\end{array}$ & & & $\begin{array}{l}-0.62 \\
(-0.40)\end{array}$ & & & $\begin{array}{l}-5.22 * \\
(-1.72)\end{array}$ \\
\hline $\begin{array}{l}\text { Below } \\
\text { Investment } \\
\text { Grade x }\end{array}$ & $(-)$ & & & $-1.69 * * *$ & & & & & \\
\hline $\begin{array}{l}\text { Incremental } \\
\text { Pension }\end{array}$ & & & & $(-2.71)$ & & & & & \\
\hline $\begin{array}{l}\text { Below } \\
\text { Investment } \\
\text { Grade } \mathrm{x}\end{array}$ & $(-)$ & & & & $-29.67 *$ & & & & \\
\hline $\begin{array}{l}\text { Pension to } \\
\text { Equity }\end{array}$ & & & & & $(-1.81)$ & & & & \\
\hline $\begin{array}{l}\text { Below } \\
\text { Investment } \\
\text { Grade x }\end{array}$ & $(-)$ & & & & & $-7.68 * * *$ & & & \\
\hline $\begin{array}{l}\text { Relative } \\
\text { Leverage }\end{array}$ & & & & & & $(-3.11)$ & & & \\
\hline High Rating & $(-)$ & $\begin{array}{l}-30.41 * * * \\
(-3.31)\end{array}$ & $\begin{array}{l}-26.82 * * * \\
(-3.38)\end{array}$ & $\begin{array}{l}-45.22 * * * \\
(-4.54)\end{array}$ & $\begin{array}{l}-38.95^{* * *} \\
(-4.02)\end{array}$ & $\begin{array}{l}-35.37 * * * \\
(-4.46)\end{array}$ & & & \\
\hline Low Rating & $(+)$ & $\begin{array}{l}123.80^{* * *} \\
(6.05)\end{array}$ & $\begin{array}{l}126.74 * * * \\
(6.13)\end{array}$ & $\begin{array}{l}127.95^{* * *} \\
(6.35)\end{array}$ & $\begin{array}{l}126.73 * * * \\
(6.42)\end{array}$ & $\begin{array}{l}133.18^{* * *} \\
(6.27)\end{array}$ & $\begin{array}{l}118.47^{* * *} \\
(4.19)\end{array}$ & $\begin{array}{l}117.14 * * * \\
(3.59)\end{array}$ & $\begin{array}{l}117.71 \text { *** } \\
(3.51)\end{array}$ \\
\hline Bond Size & $(-)$ & $\begin{array}{l}-1.78 \\
(-0.59)\end{array}$ & $\begin{array}{l}1.13 \\
(0.38)\end{array}$ & $\begin{array}{l}-1.49 \\
(-0.52)\end{array}$ & $\begin{array}{l}-1.36 \\
(-0.44)\end{array}$ & $\begin{array}{l}-0.02 \\
(-0.01)\end{array}$ & $\begin{array}{l}4.77 \\
(1.31)\end{array}$ & $\begin{array}{l}5.62 \\
(1.43)\end{array}$ & $\begin{array}{l}4.46 \\
(1.19)\end{array}$ \\
\hline Duration & $(-)$ & $\begin{array}{l}-2.20 \\
(-0.76)\end{array}$ & $\begin{array}{l}-1.48 \\
(-0.54)\end{array}$ & $\begin{array}{l}-1.65 \\
(-0.58)\end{array}$ & $\begin{array}{l}-1.58 \\
(-0.53)\end{array}$ & $\begin{array}{l}-0.42 \\
(-0.16)\end{array}$ & $\begin{array}{l}3.75 \\
(0.89)\end{array}$ & $\begin{array}{l}3.87 \\
(1.00)\end{array}$ & $\begin{array}{l}4.77 \\
(1.13)\end{array}$ \\
\hline Firm Size & $(-)$ & $\begin{array}{l}-7.23 \\
(-1.08)\end{array}$ & $\begin{array}{l}-5.72 \\
(-0.91)\end{array}$ & $\begin{array}{l}-11.53^{*} \\
(-1.85)\end{array}$ & $\begin{array}{l}-8.61 \\
(-1.35)\end{array}$ & $\begin{array}{l}-8.82 \\
(-1.38)\end{array}$ & $\begin{array}{l}8.64 \\
(0.67)\end{array}$ & $\begin{array}{l}11.96 \\
(0.79)\end{array}$ & $\begin{array}{l}13.67 \\
(0.83)\end{array}$ \\
\hline Debt Ratio & $(+)$ & $\begin{array}{l}1.15^{*} \\
(1.91)\end{array}$ & & $\begin{array}{l}1.10^{* *} \\
(2.09)\end{array}$ & $\begin{array}{l}1.10^{*} \\
(1.89)\end{array}$ & & $\begin{array}{l}1.03 \\
(1.37)\end{array}$ & $\begin{array}{l}0.96 \\
(1.06)\end{array}$ & \\
\hline Profitability & $(-)$ & $\begin{array}{l}2.87 * * \\
(1.97)\end{array}$ & $\begin{array}{l}3.55^{* * * *} \\
(3.03)\end{array}$ & $\begin{array}{l}2.72 * \\
(1.92)\end{array}$ & $\begin{array}{l}2.80 * * \\
(2.00)\end{array}$ & $\begin{array}{l}3.35 * * * \\
(3.06)\end{array}$ & $\begin{array}{l}4.99 * \\
(1.91)\end{array}$ & $\begin{array}{l}5.21^{*} \\
(1.92)\end{array}$ & $\begin{array}{l}6.20 * * * \\
(2.80)\end{array}$ \\
\hline $\begin{array}{l}\text { Market-to- } \\
\text { Book Ratio }\end{array}$ & $(-)$ & $\begin{array}{l}-59.31 * * * \\
(-5.44)\end{array}$ & $\begin{array}{l}-57.84 * * * \\
(-5.27)\end{array}$ & $\begin{array}{l}-56.71 * * * \\
(-4.84)\end{array}$ & $\begin{array}{l}-57.97 \text { *** } \\
(5.30)\end{array}$ & $\begin{array}{l}-54.06^{* * *} \\
(-5.13)\end{array}$ & $\begin{array}{l}-92.23 * * * \\
(-4.04)\end{array}$ & $\begin{array}{l}-93.77 * * * \\
(-4.33)\end{array}$ & $\begin{array}{l}-90.56^{* * *} \\
(-4.17)\end{array}$ \\
\hline Risk & $(+)$ & $\begin{array}{l}2.94 \\
(1.46)\end{array}$ & $\begin{array}{l}3.31^{*} \\
(1.71)\end{array}$ & $\begin{array}{l}2.33 \\
(1.06)\end{array}$ & $\begin{array}{l}2.89 \\
(1.39)\end{array}$ & $\begin{array}{l}2.86 \\
(1.34)\end{array}$ & $\begin{array}{l}7.53^{*} \\
(1.83)\end{array}$ & $\begin{array}{l}8.27 * * \\
(2.13)\end{array}$ & $\begin{array}{l}8.50^{* *} \\
(2.11)\end{array}$ \\
\hline Founder & $(+)$ & $\begin{array}{l}15.40 \\
(1.06)\end{array}$ & $\begin{array}{l}13.46 \\
(0.92)\end{array}$ & $\begin{array}{l}15.59 \\
(1.13)\end{array}$ & $\begin{array}{l}12.86 \\
(0.83)\end{array}$ & $\begin{array}{l}10.02 \\
(0.67)\end{array}$ & $\begin{array}{l}-5.93 \\
(-0.33)\end{array}$ & $\begin{array}{l}-7.83 \\
(-0.46)\end{array}$ & $\begin{array}{l}-7.66 \\
(-0.47)\end{array}$ \\
\hline Board Size & $(+)$ & $\begin{array}{l}-4.44 \\
(-0.14)\end{array}$ & $\begin{array}{l}-20.21 \\
(-0.69)\end{array}$ & $\begin{array}{l}3.21 \\
(0.10)\end{array}$ & $\begin{array}{l}-2.96 \\
(-0.09)\end{array}$ & $\begin{array}{l}-21.66 \\
(-0.74)\end{array}$ & $\begin{array}{l}39.63 \\
(1.01)\end{array}$ & $\begin{array}{l}28.50 \\
(0.66)\end{array}$ & $\begin{array}{l}2.92 \\
(0.09)\end{array}$ \\
\hline $\begin{array}{l}\text { Board } \\
\text { Independence }\end{array}$ & $(-)$ & $\begin{array}{l}-0.41 \\
(-0.86)\end{array}$ & $\begin{array}{l}-0.31 \\
(-0.62)\end{array}$ & $\begin{array}{l}-0.40 \\
(-0.81)\end{array}$ & $\begin{array}{l}-0.42 \\
(-0.86)\end{array}$ & $\begin{array}{l}-0.29 \\
(-0.61)\end{array}$ & $\begin{array}{l}-0.12 \\
(-0.12)\end{array}$ & $\begin{array}{l}-0.09 \\
(-0.09)\end{array}$ & $\begin{array}{l}0.02 \\
(0.02)\end{array}$ \\
\hline $\begin{array}{l}\text { Interest } \\
\text { Coverage }\end{array}$ & $(-)$ & $\begin{array}{l}-1.48 \\
(-1.18)\end{array}$ & $\begin{array}{l}-2.32 * * \\
(-2.35)\end{array}$ & $\begin{array}{l}-1.30 \\
(-1.07)\end{array}$ & $\begin{array}{l}-1.44 \\
(-1.18)\end{array}$ & $\begin{array}{l}-2.38 * * \\
(-2.36)\end{array}$ & $\begin{array}{l}0.40 \\
(0.20)\end{array}$ & $\begin{array}{l}-0.15 \\
(-0.07)\end{array}$ & $\begin{array}{l}-1.93 \\
(-1.03)\end{array}$ \\
\hline $\begin{array}{l}\text { Capital } \\
\text { Expenditure }\end{array}$ & $(+)$ & $\begin{array}{l}-2.32 \\
(-1.46)\end{array}$ & $\begin{array}{l}-1.10 \\
(-0.67)\end{array}$ & $\begin{array}{l}-2.33 \\
(-1.60)\end{array}$ & $\begin{array}{l}-2.31 \\
(-1.47)\end{array}$ & $\begin{array}{l}-1.15 \\
(-0.72)\end{array}$ & $\begin{array}{l}2.33 \\
(0.67)\end{array}$ & $\begin{array}{l}2.42 \\
(0.62)\end{array}$ & $\begin{array}{l}3.28 \\
(0.90)\end{array}$ \\
\hline
\end{tabular}


Research and Development No. of Obs. Adjusted R ${ }^{2}$

$\begin{array}{lllllllll}(+) & 4.40^{* * *} & 3.46^{* * *} & 3.82^{* * *} & 3.98^{* * *} & 3.04 * * * & -3.62 & -2.86 & -2.32 \\ (3.24) & (2.93) & (2.67) & (2.80) & (2.85) & (-0.92) & (-0.88) & (-1.06) \\ 287 & 287 & 287 & 287 & 287 & 145 & 145 & 145 \\ 0.53 & 0.53 & 0.54 & 0.54 & 0.54 & 0.55 & 0.53 & 0.53\end{array}$

